\title{
Identification of Resistance Genes to Phytophthora sojae in Domestic Soybean Cultivars from China Using Particle Bombardment
}

\author{
Jin Yang, ${ }^{1}$ Sujiao Zheng, ${ }^{1,2}$ Xiaomen Wang, ${ }^{1,2}$ Wenwu Ye, ${ }^{1,2}$ Xiaobo Zheng, ${ }^{1,2}$ and Yuanchao Wang ${ }^{1,2, \dagger}$ \\ ${ }^{1}$ Department of Plant Pathology, Nanjing Agricultural University, Nanjing, Jiangsu 210095, China \\ ${ }^{2}$ The Key Laboratory of Integrated Management of Crop Diseases and Pests (Ministry of Education), Nanjing, Jiangsu 210095 , \\ China
}

\begin{abstract}
Phytophthora root and stem rot caused by Phytophthora sojae is a destructive disease that afflicts soybean plants throughout the world. The use of resistant soybean cultivars is the primary means of managing this disease, as well as the most effective and economical approach. There are abundant soybean germplasm resources in China that could be deployed for breeding programs; however, the resistance genes (Rps genes) in most cultivars are unknown, leading to uncertainty concerning which are resistant cultivars for use. The resistance genes Rpsla, Rpslc, and Rps Ik prevent root and stem rot caused by most $P$. sojae isolates within a Chinese field population. This study identified three Rps genes in Chinese domestic soybean cultivars using three related avirulence genes by particle

identifying Rps genes quickly and specifically. We showed that cultivars Dongnong 60 and Henong 72 contained Rpsla, while Hedou 19, Henong 76, 75-3, Wandou 21020, Zheng 196, Wandou 28, Heinong 71, and Wandou 29 all contained Rpslc. The cultivars Jidou 12, Henong 72, Heinong 71, and Wandou 29 contained Rps $1 k$. The cultivar Henong 72 contained both Rps $1 a$ and Rps $1 k$, while Wandou 29 and Heinong 71 contained both Rps $1 c$ and Rps $1 k$. We then evaluated the phenotype of 11 domestic soybean cultivars reacting to $P$. sojae using the isolates P6497 and Ps1. The 11 domestic cultivars were all resistant to P6497 and Ps1. This research provides source materials and parent plant strains containing $R p s 1 a, R p s 1 c$, and Rps1k for soybean breeding programs.
\end{abstract} bombardment. The complex genetic diversity of soybean cultivars and $P$. sojae strains has made it difficult to define single Rps genes without molecular involvement. Gene cobombardment is a method for
Keywords: Avr genes, gene co-bombardment, Phytophthora sojae, Rps genes, soybean cultivars
Phytophthora root and stem rot (PRR) caused by Phytophthora sojae Kaufm. \& Gerd. is a destructive soybean disease found throughout the world (Schmitthenner 1985). This disease causes soybean seedling damping off and root rot of established plants, costing approximately $\$ 1$ to 2 billion in annual agricultural losses worldwide (Tyler 2007).

The use of resistant soybean cultivars is the most effective and economical means of managing this disease (Sugimoto et al. 2012). Many plant-pathogen interactions are determined by resistance $(R)$ genes that enable plants to recognize pathogens and induce a defense response (Grant et al. 1998). Two types of host resistance to $P$. sojae have been described: species-specific resistance determined by single dominant genes (Rps genes) (Gao et al. 2005; Sahoo et al. 2017) and broad-spectrum partial, nonspecific resistance conferred by several minor genes (field resistance, general resistance, ratereducing resistance, and tolerance) (Abeysekara et al. 2016; Dorrance 2018). Molecular markers linked to Rps genes and quantitative trait loci (QTLs) of partial resistance to P. sojae in soybean plants have

${ }^{\dagger}$ Corresponding author: Y. Wang; wangyc@ @ njau.edu.cn

Funding: This work was supported by grants to Y. Wang from the China Agriculture Research System (CARS-004-PS14), the Special Fund for Agro-scientific Research in the Public Interest of China (201303018), and the National Key R\&D Program of China (2018YFD0201000).

*The $\boldsymbol{e}$-Xtra logo stands for "electronic extra" and indicates that two supplementary tables are published online.

The author(s) declare no conflict of interest.

Accepted for publication 18 February 2020

(C) 2020 The American Phytopathological Society been reported in different populations (Abeysekara et al. 2016; Sepiol et al. 2017).

The use of resistant cultivars controlled by a single resistance (Rps) gene to combat the disease has been shown to be an effective method to prevent disease (Schmitthenner 1985). The first $R$ gene was cloned into maize 25 years ago and, since then, many $R$ genes have been identified and cloned in different plants (Kourelis and van der Hoorn 2018), providing significant information for the engineering and use of resistant plants. To date, at least $27 R p s$ genes have been identified in soybean plants, including Rpsla, Rps1b, Rps1c, Rps1d, Rps 1 , Rps2, Rps3a, Rps3b, Rps3c, Rps4, Rps5, Rps6, Rps7 (Dorrance et al. 2004), Rps8 (Sandhu et al. 2005), Rps9 (Wu et al. 2011), Rps10 (Zhang et al. 2013), Rps11 (Ping et al. 2016), Rps12 (Sahoo et al. 2017), RpsYD25 (Fan et al. 2009), RpsYu25 (Sun et al. 2011), RpsYD29 (Zhang et al. 2014), RpsUN1 (Li et al. 2016), RpsJS (Sun et al. 2014), RpsSN10 (Yu et al. 2010), RpsYB30 (Zhu et al. 2007), RpsWaseshiroge (Zhang et al. 2013), and RpsZS18 (Zhong et al. 2018).

Rps1a was the first Rps gene widely deployed in soybean grown in the United States (Schmitthenner 1985). In the past several decades, $R p s 1 k$ has become the most stable and widely used gene in major soybean-producing regions of the United States (Gao et al. 2005; Yan and Nelson 2019). Rpsld and Rpslk were the most effective resistance genes within Japan in 2010 (Sugimoto et al. 2012). Rpslc was also employed in the United States for many years (Beuerlein et al. 2000; Slaminko et al. 2010).

There are abundant soybean germplasm resources in China for use in breeding programs incorporating a variety of techniques. The hypocotyl inoculation method was commonly used in resistance evaluation assays (Huang et al. 2016; Slaminko et al. 2010; Zhu et al. 2007). Jiang et al. (2017) used a method in which, $P$. sojae inoculum was mixed into soil and resistance was evaluated by the survival rate (percentage) of soybean seedlings (mixing agar homogenate containing P. sojae into the soil). Arsenault-Labrecque et al. (2018) 
developed a simple hydroponic assay to study resistance in soybean. However, Rps genes in most cultivars are uncharacterized, particularly in domestic cultivars, leading to uncertainty during resistant cultivar usage. Previous reports on cultivars containing Rps1a, Rps1c, and Rpslk suggest that these strains could be resistant to most of the P. sojae isolates in China (Cui 2010; Tang et al. 2011; Yang et al. 2019). Thus, use of cultivars containing these three Rps genes may be effective in the management of soybean disease in China.

To investigate Rps genes in domestic soybean cultivars within China, we collected 40 domestic soybean cultivars from the major soybean-producing regions and used a gene cobombardment method. This study provides source materials and identification of parent plants that contain Rpsla, Rpslc, and Rpslk for soybean breeding programs.

\section{Materials and Methods}

Soybean cultivars and $\boldsymbol{P}$. sojae cultivation. Seed of cultivars Williams (rps), Harlon (Rpsla), Williams 79 (Rps1c), and Williams 82 (Rps $1 k$ ) were provided by Prof. Han Xing at Nanjing Agricultural University. Cultivar Hedou 19 was from Shandong Province; Henong 72, Henong 76, Heinong 71, and Dongnong 60 were from Heilongjiang Province; 75-3 was from Fujian Province; Jidou 12 was from Hebei Province; Wandou 21020, Wandou 28, and Wandou 29 were from Anhui Province; and Zheng 196 was from Henan Province. The ancestral parents and origins are provided in Supplementary Table S1. Soybean cultivars were grown in a greenhouse at $25^{\circ} \mathrm{C}$ with a cycle of $14 \mathrm{~h}$ of light and $10 \mathrm{~h}$ of darkness.

$P$. sojae isolates P6497 and Ps1 used in this study were stored in $10 \%$ vegetable (V8) juice agar medium at 10 to $12^{\circ} \mathrm{C}$ in the dark. Each isolate was isolated from a single zoospore. The isolates were grown in $10 \% \mathrm{~V} 8$ juice agar medium at $25^{\circ} \mathrm{C}$ in the dark for transferring and inoculation.

Inoculation assay. Soybean seedlings were grown in vermiculite soaked with sterilized water at $25^{\circ} \mathrm{C}$ during the day $(14 \mathrm{~h})$ and at night $(10 \mathrm{~h}$ ) for 4 days prior to harvest for inoculation assays (Dong et al. 2009). The vermiculite was washed off for disease assays. A 5-mmdiameter mycelial plug, cut from the growing edge of 7-day-old $P$. sojae cultures, was placed on the hypocotyls of etiolated seedlings, 2 to $3 \mathrm{~cm}$ from the base of the cotyledon, mycelial-side down. This was done for 10 plants per cultivar and repeated two times. A 5-mm-diameter inoculum-free $10 \% \mathrm{~V} 8$ agar plug was used as a blank control. The seedling roots and inoculation sites were covered with papers soaked with sterilized water to maintain humidity, with plastic bag coverings used to maintain humidity for 4 days. The inoculated plants were then placed in the dark at $25^{\circ} \mathrm{C}$.

Resistance phenotypes were determined at 4 days postinoculation. A cultivar was characterized as resistant when more than 7 of 10 plants were similar to the blank control or exhibited soft red-brown patches only at the inoculated sites with normal root growth. If the water-soaked or red-brown patch had expanded from the inoculated sites on more than three plants and the roots were barely developed, the cultivar was classified as susceptible. If the lesion appeared only at the inoculation site (whether or not it encompassed the stem) and the roots were normal compared with the control in more than three plants, or if the number of healthy plants ranged from 4 to 6 , then the cultivar was identified as having intermediate resistance. If there were differences between the two assays, the assay was repeated for a third time and the response of two of the three assays was recorded. Assays producing intermediate resistance reactions were repeated until the result was consistent. The phenotypes of each cultivar were scored as resistant, susceptible, or intermediate.

Plasmid construction. Avirulence (Avr) genes Avrla, Avrlc, and Avrlk alleles without a signal peptide were cloned from genomic DNA of $P$. sojae isolate P6497 (Supplementary Table S2). For gene cobombardment experiments, all the amplified fragments were purified by the Agarose Gel DNA Purification Kit (TaKaRa) following the manufacturer's instructions. The purified fragments were infused using a ClonExpressII One Step Cloning Kit (Vazyme, Nanjing, China) into pFF19, which was linearized by restriction enzyme SmaI (New England Biolabs, Ipswich, MA, U.S.A.) (Timmermans et al. 1990). Individual colonies of each construct were tested by PCR and verified by sequencing. The cloning primers are shown in Table 1 .

Gene cobombardment of soybean leaves. Avrla, Avrlc, and $A v r l k$ alleles were amplified using a pair of primers without a signal peptide, infused into plasmid pFF19 (replacing $\beta$-glucuronidase $[G U S]$ ), and digested by SmaI (Kong et al. 2015). Double- or quadruple-barreled particle bombardment assays were performed on 12- or 13-day-old soybean leaves containing GUS DNA and empty vector (EV), or GUS and Avr genes, using a Bio- $\mathrm{Rad} \mathrm{He} /$ 1000 Particle Delivery System (Hercules, CA, U.S.A.) (Dou et al. 2008 b) to enable target leaves to be bombarded with two DNA preparations simultaneously.

In total, $60 \mathrm{mg}$ of $0.6-\mu \mathrm{m}$ gold microcarrier particles (Bio-Rad) was washed twice with $75 \%$ ethanol and three times with sterile deionized water, then suspended in 50\% sterile glycerol to a concentration of $60 \mathrm{mg} / \mathrm{ml}$, and $50 \mu \mathrm{l}$ was placed in each tube. For bombardment experiments, particles $(50 \mu \mathrm{l})$ were combined with $10 \mu \mathrm{g}$ of GUS plasmid DNA (PFF19-GUS) and test DNA or EV (pFF19) as the control in a $1.5-\mathrm{ml}$ centrifuge tube. Then, $70 \mu \mathrm{l}$ of $2.5 \mathrm{M} \mathrm{CaCl}_{2}$ was added to the reaction, followed by $30 \mu \mathrm{l}$ of freshly prepared $0.1 \mathrm{M}$ spermidine. The preparation was vortexed vigorously for $5 \mathrm{~min}$, then pulsed for another $5 \mathrm{~min}$. The particle preparation was then concentrated to $10 \mu$ l by brief centrifugation.

Soybean leaves were hydrated for 2 days in the dark at $25^{\circ} \mathrm{C}$. The leaves were stained for 12 to $24 \mathrm{~h}$ at $37^{\circ} \mathrm{C}$ with 5-bromo-4-chloro-3indolyl- $\beta$-D-glucuronic acid (cyclohexylammonium salt) at $0.5 \mathrm{mg} / \mathrm{ml}$, $80 \mathrm{mM}$ sodium phosphate, $0.4 \mathrm{mM}$ potassium ferricyanide, $0.4 \mathrm{mM}$ potassium ferrocyanide, $10 \mathrm{mM}$ disodium EDTA ( $\mathrm{pH} \mathrm{8.0)}$ ), and $0.1 \%$ (vol/vol) Triton X-100, then destained in $75 \%$ ethanol until the chlorophyll was destained enough to take clear photos.

For each pair of photos, the ratio of the number of blue spots with various $A v r$ gene constructs to the EV control was calculated. Each assay consisted of five pairs of photos and was conducted at least twice. For quadruple-barreled particle bombardment assays, the numbers of blue spots of the three $A v r$ genes were compared with the EV expressed in the same leaves. Each assay consisted of five pairs of images and at least three biological replicates were performed.

\section{Results}

The three Avr genes are recognized by the cognate Rps genes. To investigate the resistance genes of domestic soybean cultivars in China, three similar $A v r$ genes were transiently expressed in soybean leaves. The Avr genes Avrla, Avrlc, and Avrlk were constructed into plasmid pFF19 without a signal peptide. The $A v r$ genes, together with the reporter gene $G U S$, were expressed in leaves of the Williams (rps), Harlon (Rpsla), Williams 79 (Rpslc), and Williams 82 (Rps 1k)

Table 1. Primers used in this study

\begin{tabular}{ll}
\hline Primers & \multicolumn{1}{c}{ Sequence $\mathbf{5}^{\prime} \rightarrow \mathbf{3}^{\prime}$} \\
\hline pFF19-Avr1a-F & GCTTTCGCGAGCTCGGTACCCGGGATGGCAGCAACTGATGCCGAC \\
pFF19-Avr1a-R & GGTCGACTCTAGAGGATCCCCGGGCTACCAGTCTTTATAATTCCTG \\
pFF19-Avr1c-F2 & GCTTTCGCGAGCTCGGTACCCGGGATGGCAGCAACTGATGCCGAC \\
pFF19-Avr1c-R2 & GGTCGACTCTAGAGGATCCCCGGGCTAATGACCTCTCAAGTGGAATAC \\
pFF19-Avr1k-F & GCTTTCGCGAGCTCGGTACCCGGGATGCTCACTTGCGCCACCTCCGAG \\
pFF19-Avr1k-R & GGTCGACTCTAGAGGATCCCCGGGTCAGATAATCATGATGCTGTTC \\
\hline
\end{tabular}


cultivars using double-barreled particle bombardment. Blue spots indicating surviving cells were counted. Our results showed that there was no significant difference in the number of surviving cells in Williams ( $r p s$ ) leaves expressing the three $A v r$ genes compared with that of the EV. The amount of pFF19-Avrla gene expressed in Harlon (Rpsla) was adjusted to $100,300,500,700$, or 1,000 ng, and the results showed that plasmid amounts of $500 \mathrm{ng}$ and higher significantly induced cell death in Harlon leaves. When the amount of pFF19-Avrlc gene expressed in Williams 79 (Rpslc) was adjusted to $100 \mathrm{ng}$, $500 \mathrm{ng}, 1 \mu \mathrm{g}, 2 \mu \mathrm{g}, 4 \mu \mathrm{g}$, or $8 \mu \mathrm{g}$, we observed that 4 to $5 \mu \mathrm{g}$ and higher of pFF19-Avrlc significantly induced cell death in Williams 79 leaves. For the Avrlk gene, we altered the plasmid quantity to $100 \mathrm{ng}, 500 \mathrm{ng}, 1 \mu \mathrm{g}, 2 \mu \mathrm{g}, 4 \mu \mathrm{g}, 8 \mu \mathrm{g}, 10 \mu \mathrm{g}, 12 \mu \mathrm{g}$, and $14 \mu \mathrm{g}$, and demonstrated that $10 \mu \mathrm{g}$ and higher of plasmid significantly induced cell death in Williams 82 (Rpslk) (Fig. 1).

Identification of $R$ ps genes in domestic soybean cultivars. Although there are abundant soybean germplasm resources in China, resistance to $P$. sojae and the presence of Rps genes in these resources remains unknown. We collected 40 domestic soybean cultivars in major soybean production regions from China to identify the Rps genes contained in those domestic cultivars. The leaves of 12- to 13-day-old soybean plants of 40 domestic cultivars were harvested to transiently express three Avr genes. The cultivars Williams, Dongnong 60 , Jidou 12, Henong 72, Hedou 19, Henong 76, 75-3, Wandou 21020, Wandou 29, and Hefeng 50 all showed cell death when the three Avr genes with GUS were transiently expressed using double-barreled particle bombardment assays. There were significantly fewer spots in cultivars Dongnong 60 and Henong 72 expressing Avrla compared with the EV, indicating that the cultivars Dongnong 60 and Henong 72 contain Rpsla. Similarly, Hedou 19, Henong 76, 75-3, Wandou 21020, and Wandou 29 all contain Rpslc. The cultivars Jidou 12, Henong 72, and Wandou 29 contain Rpslk.

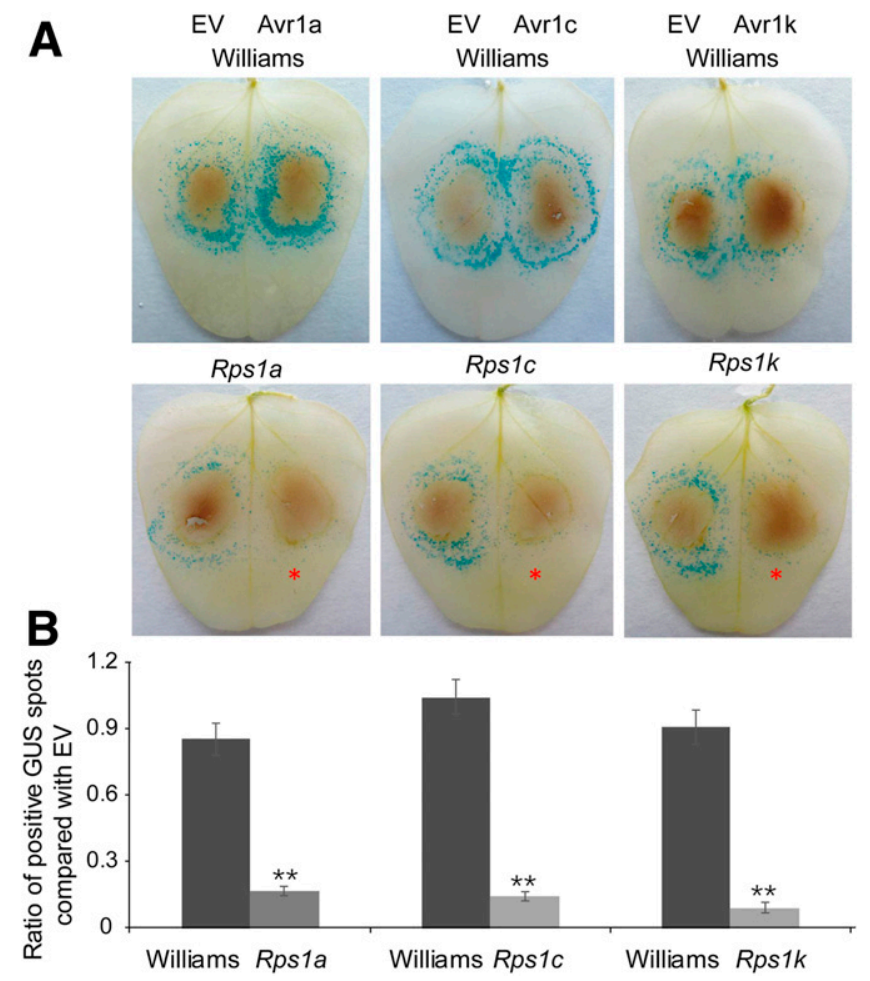

Fig. 1. Three avirulence (Avr) genes are recognized by cognate single dominant resistance (Rps) genes. A, Response of Avr1a, Avr1c, and Avr1k transiently expressed in Williams (rps), Harlon (Rps1a), Williams 79 (Rps1c), and Williams 82 (Rps1k) cultivars. Blue spots represent surviving cells and red asterisks indicate cell death. B, Ratio of $\beta$-glucuronidase (GUS)-positive blue spots following bombardment with Avr genes compared with the empty vector (EV) control. Error bars represent standard error from three independent replicates. Asterisks $\left(^{* *}\right)$ indicate $P<0.01$ determined by $t$ test.
The cultivar Henong 72 contains both Rps $1 a$ and Rps $1 k$, while Wandou 29 contains both Rps $1 c$ and Rps $1 k$. The cultivars Williams and Hefeng 50 were used as controls (Fig. 2; Supplementary Table S1).

The Avr genes were transiently expressed in the cultivars Williams, Zheng 196, Heinong 71, Wandou 28, and Kenfeng 23 using quadruple-barreled particle bombardment assays (Fig. 3). The ratio of blue spots that expressed the three Avr genes compared with the EV was calculated for each cultivar. Our results indicated that Zheng 196 contains Rpslc, Heinong 71 contains both Rps $1 c$ and Rps $1 k$, and Wandou 28 contains Rpslc, whereas Kenfeng 23 contains none of the three Rps genes.

In all, 11 of the 40 domestic soybean cultivars from China contained Rpsla, Rpslc, Rpslk or a combination of the three Rps genes (Supplementary Table S1). Three cultivars contained Rpsla, nine cultivars contained Rpslc, and five cultivars contained Rps $1 k$. Two cultivars contained Rps $1 c$ and Rpslk while one cultivar contained $R p s l a$ and Rpslk. Twenty-nine cultivars contained none of the three Rps genes.

Phenotypic evaluation of resistance of domestic cultivars in China to $\boldsymbol{P}$. sojae. To further investigate the resistance of cultivars containing the three Rps genes, we evaluated the reaction of 11 domestic soybean cultivars to P. sojae using the isolates P6497 (pathotype $1 \mathrm{~b}, 7$ ) and Ps1 (pathotype 7), which contain the three $A v r$ genes: Avrla, Avrlc, and Avrlk. The Williams cultivar was used as a susceptible control and the Hefeng 50 cultivar was used as a resistant control. The 11 cultivars containing Rps genes were all resistant to isolates Ps1 (pathotype 7) and P6497 (pathotype 1b, 7) (Fig. 4).

\section{Discussion}

Since the first $R$ gene $(\mathrm{Hml})$ found in Zea mays was cloned in 1990 , several different $R$ genes in various plants have been identified and cloned (Kourelis and van der Hoorn 2018). Molecular identification and functional determination are crucial for molecular engineering and correct usage of $R$ genes in plant breeding programs. The genome of the soybean plant is approximately $1.1 \mathrm{~Gb}$ and genome duplications occurred approximately 59 and 13 million years ago, resulting in a highly duplicated genome with nearly $75 \%$ of genes present in multiple copies (Schmutz et al. 2010). The complexity of the soybean genome makes it difficult to clone soybean genes. An accurate soybean genome sequence of Williams 82 was completed in 2010; this has facilitated identification of many soybean traits (Schmutz et al. 2010).

Generally, resistance to plant pathogens is controlled by a single $R p s$ gene and would only be effective for 8 to 15 years due to rapid evolution of pathogens under high selection pressure in the field (Schmitthenner 1985). Stacking multiple Rps genes or combining QTLs into a single cultivar is considered an effective strategy to ensure durable, broad-spectrum resistance (Dorrance et al. 2009). Recently, $R p s X$ in the soybean cultivar Xiu94-11 was reported to exhibit broad-spectrum PRR resistance (Zhong et al. 2019). Nevertheless, single dominant Rps genes have been highly effective in managing stem rot disease. To date, at least 28 Rps genes have been identified in the soybean genome; several nucleotide-binding site leucine-rich repeat receptor (NLR) genes have also been recorded (Gao et al. 2005; Ping et al. 2016). There are few cultivars currently identified with Rps genes, particularly domestic soybean cultivars.

Most $R$ genes were previously cloned using a map-based cloning strategy in rice, maize, wheat, and soybean (Dai et al. 2007; Kourelis and van der Hoorn 2018; Zhao et al. 2013; Zhong et al. 2019). The traditional method of identifying Rps genes was to expose cultivars to $P$. sojae isolates and see if resistance was present. A hypocotylslit inoculation method was commonly used in soybean resistance identification assays (Huang et al. 2016; Slaminko et al. 2010; Zhu et al. 2007). Jiang et al. (2017) used a modified method in which $P$. sojae isolate inoculum was mixed into soil and resistance was evaluated by the survival rate (percentage) of soybean seedlings. Arsenault-Labrecque et al. (2018) developed a simple hydroponic assay to study resistance in soybean using different isolates. Then, the Rps genes were postulated in soybean cultivars according to the 
resistance to various isolates (Kyle et al. 1998; Wu et al. 2010). However, the complex genetic diversity of soybean cultivars and $P$. sojae strains has made it difficult to define single Rps genes without molecular involvement. Gene cobombardment is an established transient expression technique for soybean genomics (Dou et al. $2008 \mathrm{a}, \mathrm{b}$; Huang et al. 2019; Kong et al. 2015; Na et al. 2013; Song et al. 2013). This is the first report to identify Rps genes in a significant number of cultivars using this technique. We first used a quadruplebarreled particle bombardment assay, which allows expression of four genes simultaneously in soybean leaves and was more effective for identification. We then tested the cultivar phenotypes against isolates P6497 and Ps1, each of which contained the three Avr genes. The 11 domestic cultivars that expressed Rps genes were resistant to both isolates, suggesting that the Rps genes we identified will be useful

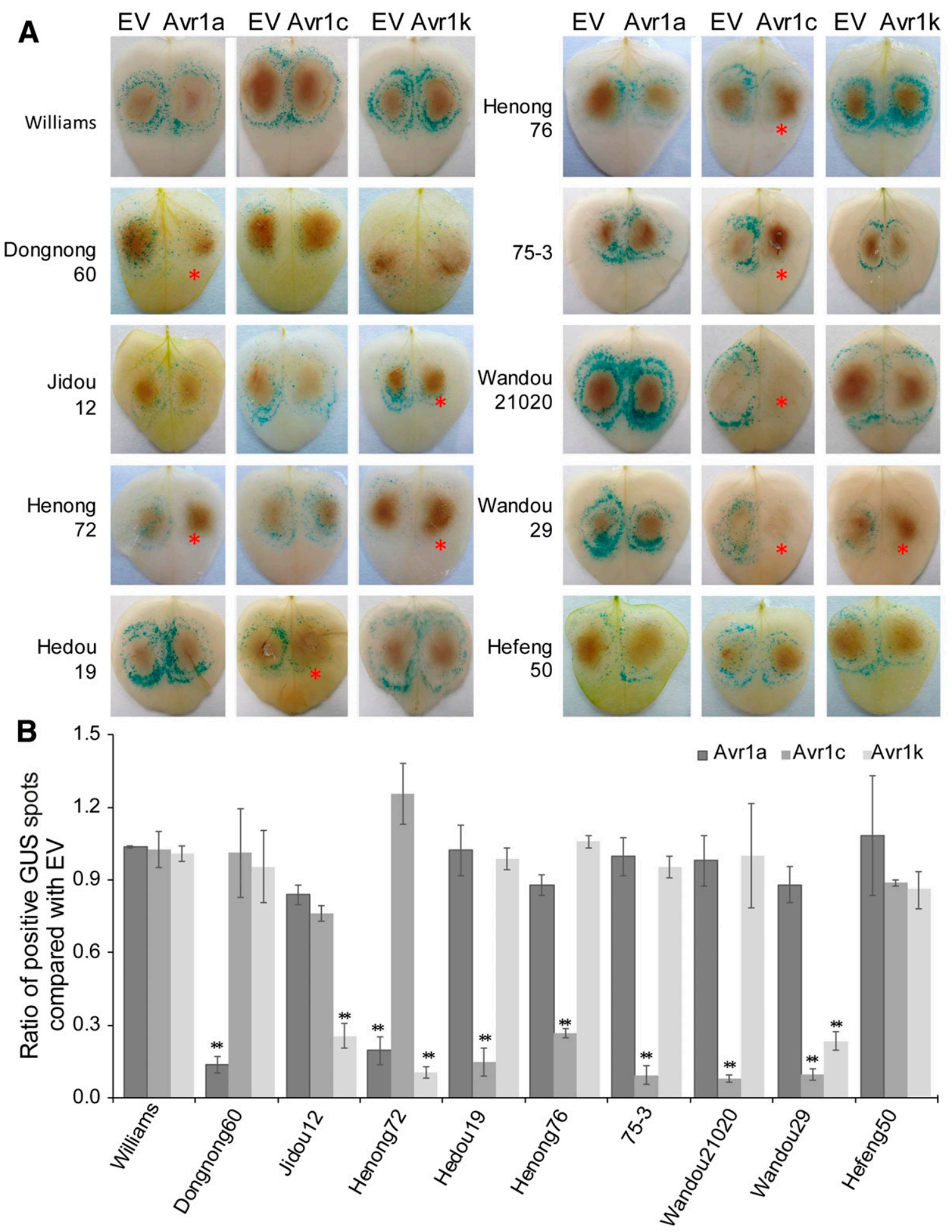

Cultivars

Fig. 2. Response of cultivars expressing the three avirulence (Avr) genes. A, The 10 cultivars transiently expressing the three Avr genes. Blue spots represent surviving cells and red asterisks indicate cell death. B, Ratio of $\beta$-glucuronidase (GUS)-positive blue spots following bombardment with Avr genes compared with the empty vector (EV). Cultivar Hefeng 50 was used as a control. Error bars represent standard error from three independent replicates. Asterisks $\left(^{* *}\right)$ indicate $P<0.01$ determined by $t$ test. 
against PRR. Wandou 28, Wandou 29, and Hedou 19 were all resistant to Ps1 (pathotype 7), Ps3 (1a, 7), Ps4 (1a, 1c, 7), Ps5 (1a, 1c, 6, 7), PsUSAR2 (1b, 2, 3c, 5, 7), Ps41-1 (1a, 1d, 2, 3b, 3c, 5, 7, 8), PsMC1 (1a, 1c, 1k, 2, 3b, 3c, 4, 5, 6, 7, 8), and PsJS2 (1a, 1b, 1c, 1d, 1k, 2, 3a, 3b, 3c, 4, 5, 6, 7, and 8) (Yang et al. 2020).

Rpslc, Rpsla, and Rpslk are the most commonly used resistance genes in the United States (Schmitthenner 1985; Slaminko et al. 2010). These Rps genes can defend against the most $P$. sojae isolates in a Chinese field population (Tang et al. 2011; Yang et al. 2019). We collected 40 domestic soybean cultivars from major Chinese soybean-producing regions, including Heilongjiang, Henan, Jiangsu, Anhui, and Fujian Provinces, to conduct this survey. Within a group of 11 domestic soybean cultivars, 2 cultivars contained Rps $1 a$ genes, 8 cultivars contained $R p s l c$, and 4 cultivars contained Rps $1 k$. Meanwhile, 29 cultivars did not contain any of the three known Rps genes. Our results indicated that the resistance gene Rpslc was the most

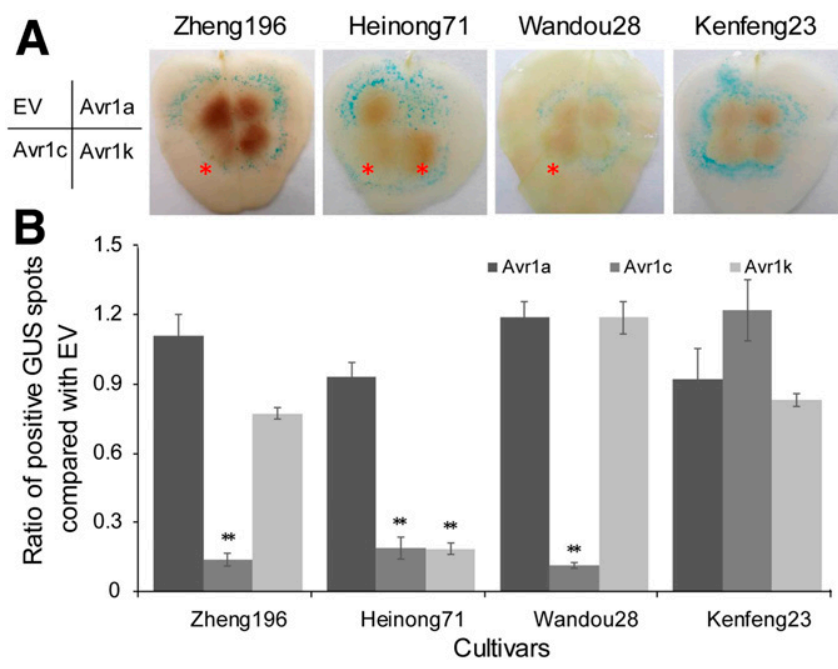

Fig. 3. Response of cultivars expressing all three avirulence (Avr) genes. A, Four cultivars transiently expressing all three Avr genes simultaneously. Blue spots represent surviving cells while the red asterisks indicate cell death. B, Ratio of $\beta$-glucuronidase (GUS)-positive blue spots following bombardment with Avr genes compared with the empty vector (EV). Cultivar Kenfeng 23 was used as a control. Error bars represent standard error from three independent replicates. Asterisks $\left({ }^{* *}\right)$ indicate $P<0.01$ determined by $t$ test.

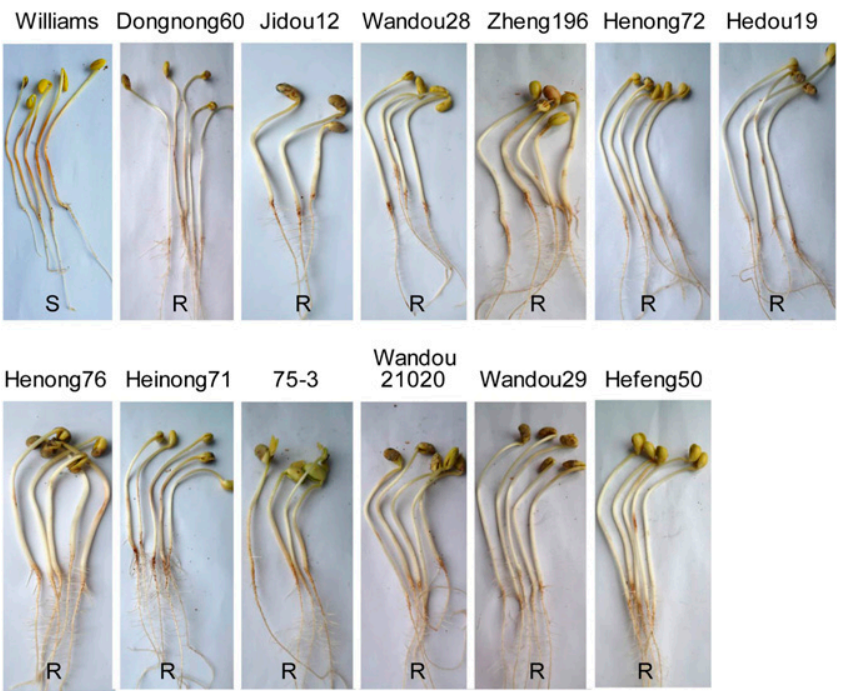

Fig. 4. Phenotypic evaluation of resistance to Phytophthora sojae P6497. Cultivar Williams was used as a susceptible control and cultivar Hefeng 50 was used as a resistant control. $\mathrm{R}=$ resistant and $\mathrm{S}=$ susceptible. common in Chinese domestic soybean cultivars. The two cultivars containing Rps la were both from Heilongjiang Province. The cultivars containing Rps $1 k$ were from Anhui and Heilongjiang Province, while the cultivars containing Rps $1 c$ were distributed in every region tested.

We first identified Rps genes in soybean cultivars using double- or quadruple-barreled particle bombardment assays. Our research has provided knowledge of parent plants that contain Rpsla, Rpslc, and Rps $1 k$ for breeders to stack several Rps genes together to develop more resistant and durable soybean cultivars.

\section{Acknowledgments}

We thank the breeders from Heilongjiang, Henan, Anhui, Jiangsu, and Fujian Provinces for providing us the seed of domestic cultivars.

\section{Literature Cited}

Abeysekara, N. S., Matthiesen, R. L., Cianzio, S. R., Bhattacharyya, M. K., and Robertson, A. E. 2016. Novel sources of partial resistance against Phytophthora sojae in soybean PI 399036. Crop Sci. 56:2322-2335.

Arsenault-Labrecque, G., Sonah, H., Lebreton, A., Labbe, C., Marchand, G., Xue, A., Belzile, F., Knaus, B. J., Grunwald, N. J., and Belanger, R. R. 2018. Stable predictive markers for Phytophthora sojae avirulence genes that impair infection of soybean uncovered by whole genome sequencing of 31 isolates. BMC Biol. 16:80.

Beuerlein, J. E., St. Martin, S., and Dorrance, A. E. 2000. Studies on distribution and virulence structure of Phytophthora sojae in China. Chapter 1 in: Ohio Soybean Performance Trials. Ohio State Univ. Dep. Hortic. Crop Sci. Ser. 212.

Cui, L. K. 2010. Pages 36-43 in: Study on Virulence Composition, Genetic Structure and Polymorphism of Avr Genes in Phytophthora sojae in China. Nanjing Agricultural University, Nanjing, China.

Dai, L. Y., Liu, X. L., Xiao, Y. H., and Wang, G. L. 2007. Recent advances in cloning and characterization of disease resistance genes in rice. J. Integr. Plant Biol. 49:112-119.

Dong, S., Qutob, D., Tedman-Jones, J., Kuflu, K., Wang, Y., Tyler, B. M., and Gijzen, M. 2009. The Phytophthora sojae avirulence locus Avr3c encodes a multi-copy RXLR effector with sequence polymorphisms among pathogen strains. PLoS One 4:e5556.

Dorrance, A. E. 2018. Management of Phytophthora sojae of soybean: A review and future perspectives. Can. J. Plant Pathol. 40:210-219.

Dorrance, A. E., Jia, H., and Abney, T. S. 2004. Evaluation of soybean differentials for their interaction with Phytophthora sojae. Plant Health Prog. 5.

Dorrance, A. E., Robertson, A. E., Cianzo, S., Giesler, L. J., Grau, C. R., Draper M. A., Tenuta, A. U., and Anderson, T. R. 2009. Integrated management strategies for Phytophthora sojae combining host resistance and seed treatments. Plant Dis. 93:875-882.

Dou, D., Kale, S. D., Wang, X., Chen, Y., Wang, Q., Wang, X., Jiang, R. H., Arredondo, F. D., Anderson, R. G., Thakur, P. B., McDowell, J. M., Wang, Y., and Tyler, B. M. 2008a. Conserved C-terminal motifs required for avirulence and suppression of cell death by Phytophthora sojae effector Avr1b. Plant Cell 20:1118-1133.

Dou, D., Kale, S. D., Wang, X., Jiang, R. H., Bruce, N. A., Arredondo, F. D., Zhang, X., and Tyler, B. M. 2008b. RXLR-mediated entry of Phytophthora sojae effector Avrlb into soybean cells does not require pathogen-encoded machinery. Plant Cell 20:1930-1947.

Fan, A. Y., Wang, X. M., Fang, X. P., Wu, X. F., and Zhu, Z. D. 2009. Molecular identification of Phytophthora resistance gene in soybean cultivar Yudou 25 Acta Agron. Sin. 35:1844-1850.

Gao, H. Y., Narayanan, N. N., Ellison, L., and Bhattacharyya, M. K. 2005. Two classes of highly similar coiled coil-nucleotide binding-leucine rich repeat genes isolated from the Rps1-k locus encode Phytophthora resistance in soybean. Mol. Plant-Microbe Interact. 18:1035-1045.

Grant, M. R., McDowell, J. M., Sharpe, A. G., de Torres Zabala, M., Lydiate, D. J., and Dangl, J. L. 1998. Independent deletions of a pathogenresistance gene in Brassica and Arabidopsis. Proc. Natl. Acad. Sci. U.S.A. 95:15843-15848.

Huang, J., Chen, L., Lu, X., Peng, Q., Zhang, Y., Yang, J., Zhang, B. Y., Yang, B., Waletich, J. R., Yin, W., Zheng, X., Wang, Y., and Dong, S. 2019. Natural allelic variations provide insights into host adaptation of Phytophthora avirulence effector PsAvr3c. New Phytol. 221:1010-1022.

Huang, J., Guo, N., Li, Y., Sun, J., Hu, G., Zhang, H., Li, Y., Zhang, X., Zhao, J. Xing, H., and Qiu, L. 2016. Phenotypic evaluation and genetic dissection of resistance to Phytophthora sojae in the Chinese soybean mini core collection. BMC Genet. 17:85.

Jiang, C. J., Sugano, S., Kaga, A., Lee, S. S., Sugimoto, T., Takahashi, M., and Ishimoto, M. 2017. Evaluation of resistance to Phytophthora sojae in soybean mini core collections using an improved assay system. Phytopathology 107:216-223.

Kong, G., Zhao, Y., Jing, M., Huang, J., Yang, J., Xia, Y., Kong, L., Ye, W., Xiong, Q., Qiao, Y., Dong, S., Ma, W., and Wang, Y. 2015. The activation 
of Phytophthora effector Avr3b by plant cyclophilin is required for the nudix hydrolase activity of Avr3b. PLoS Pathog. 11:e1005139.

Kourelis, J., and van der Hoorn, R. A. L. 2018. Defended to the nines: 25 years of resistance gene cloning identifies nine mechanisms for $\mathrm{R}$ protein function. Plant Cell 30:285-299.

Kyle, D. E., Nickell, C. D., Nelson, R. L., and Pedersen, W. L. 1998. Response of soybean accessions from provinces in southern China to Phytophthora sojae. Plant Dis. 82:555-559.

Li, L., Lin, F., Wang, W., Ping, J., Fitzgerald, J. C., Zhao, M., Li, S., Sun, L., Cai, C., and Ma, J. 2016. Fine mapping and candidate gene analysis of two loci conferring resistance to Phytophthora sojae in soybean. Theor. Appl. Genet. 129:2379-2386.

Na, R., Yu, D., Qutob, D., Zhao, J., and Gijzen, M. 2013. Deletion of the Phytophthora sojae avirulence gene Avrld causes gain of virulence on Rpsld. Mol. Plant-Microbe Interact. 26:969-976.

Ping, J. Q., Fitzgerald, J. C., Zhang, C. B., Lin, F., Bai, Y. H., Wang, D. C., Aggarwal, R., Rehman, M., Crasta, O., and Ma, J. X. 2016. Identification and molecular mapping of Rps11, a novel gene conferring resistance to Phytophthora sojae in soybean. Theor. Appl. Genet. 129:445-451.

Sahoo, D. K., Abeysekara, N. S., Cianzio, S. R., Robertson, A. E., and Bhattacharyya, M. K. 2017. A novel Phytophthora sojae resistance Rps 12 gene mapped to a genomic region that contains several Rps genes. PLoS One 12:e0169950.

Sandhu, D., Schallock, K. G., Rivera-Velez, N., Lundeen, P., Cianzio, S., and Bhattacharyya, M. K. 2005. Soybean Phytophthora resistance gene Rps8 maps closely to the Rps3 region. J. Hered. 96:536-541.

Schmitthenner, A. F. 1985. Problems and progress in control of Phytophthora root rot of soybean. Plant Dis. 69:362-368.

Schmutz, J., Cannon, S. B., Schlueter, J., Ma, J., Mitros, T., Nelson, W., Hyten, D. L., Song, Q., Thelen, J. J., Cheng, J., Xu, D., Hellsten, U., May, G. D., Yu, Y., Sakurai, T., Umezawa, T., Bhattacharyya, M. K., Sandhu, D., Valliyodan, B., Lindquist, E., Peto, M., Grant, D., Shu, S., Goodstein, D., Barry, K., Futrell-Griggs, M., Abernathy, B., Du, J., Tian, Z., Zhu, L., Gill, N., Joshi, T., Libault, M., Sethuraman, A., Zhang, X. C., Shinozaki, K., Nguyen, H. T., Wing, R. A., Cregan, P., Specht, J., Grimwood, J., Rokhsar, D., Stacey, G., Shoemaker, R. C., and Jackson, S. A. 2010. Genome sequence of the palaeopolyploid soybean. Nature 463:178-183.

Sepiol, C. J., Yu, J., and Dhaubhadel, S. 2017. Genome-wide identification of chalcone reductase gene family in soybean: Insight into root-specific GmCHRs and Phytophthora sojae resistance. Front. Plant Sci. 8:2073.

Slaminko, T. L., Bowen, C. R., and Hartman, G. L. 2010. Multi-year evaluation of commercial soybean cultivars for resistance to Phytophthora sojae. Plant Dis. 94:368-371

Song, T., Kale, S. D., Arredondo, F. D., Shen, D., Su, L., Liu, L., Wu, Y., Wang, Y., Dou, D., and Tyler, B. M. 2013. Two RxLR avirulence genes in Phytophthora sojae determine soybean Rpslk-mediated disease resistance. Mol. Plant-Microbe Interact. 26:711-720.

Sugimoto, T., Kato, M., Yoshida, S., Matsumoto, I., Kobayashi, T., Kaga, A., Hajika, M., Yamamoto, R., Watanabe, K., Aino, M., Matoh, T., Walker, D. R., Biggs, A. R., and Ishimoto, M. 2012. Pathogenic diversity of Phytophthora sojae and breeding strategies to develop Phytophthora-resistant soybeans. Breed. Sci. 61:511-522.

Sun, J. T., Li, L. H., Zhao, J. M., Huang, J., Yan, Q., Xing, H., and Guo, N. 2014. Genetic analysis and fine mapping of RpsJS, a novel resistance gene to
Phytophthora sojae in soybean [Glycine max (L.) Merr]. Theor. Appl. Genet. 127:913-919.

Sun, S., Wu, X. L., Zhao, J. M., Wang, Y. C., Tang, Q. H., Yu, D. Y., Gai, J. Y., and Xing, H. 2011. Characterization and mapping of RpsYu25, a novel resistance gene to Phytophthora sojae. Plant Breed. 130:139-143.

Tang, Q., Cui, L., Li, D., Dai, T., Yin, W., Dong, S., Xing, H., Zheng, X., and Wang, Y. 2011. Resistance evaluation of soybean germplasm from Huanghuai region to Phytophthora root rot. Agric. Sci. China 10:246-251.

Timmermans, M. C. P., Maliga, P., Vieira, J., and Messing, J. 1990. The pFF plasmids: Cassettes utilising CaMV sequences for expression of foreign genes in plants. J. Biotechnol. 14:333-344.

Tyler, B. M. 2007. Phytophthora sojae: Root rot pathogen of soybean and model oomycete. Mol. Plant Pathol. 8:1-8.

Wu, X. L., Yang, F., Xing, H., Zhao, J. M., Wang, Y. C., Sun, S., and Gai, J. Y. 2010. A survey of soybean germplasm for resistance to Phytophthora sojae. Euphytica 176:261-268.

Wu, X. L., Zhang, B. Q., Sun, S., Zhao, J. M., Yang, F., Guo, N., Gai, J. Y., and Xing, H. 2011. Identification, genetic analysis and mapping of resistance to Phytophthora sojae of Pm28 in soybean. Agric. Sci. China 10:1506-1511.

Yan, H., and Nelson, B., Jr. 2019. Adaptation of Phytophthora sojae to Rps resistance genes over the past two decades in North Dakota. Plant Health Prog. 20:88-93.

Yang, J., Wang, X., Guo, B., Huang, J., Ye, W., Dong, S., Wang, Y., Zheng, X., and Wang, Y. 2019. Polymorphism in natural alleles of the avirulence gene Avrlc is associated with the host adaptation of Phytophthora sojae. Phytopathol. Res. 1:28.

Yang, J., Ye, W., Wang, X., Ren, L., Yao, Y., Wang, X., Wang, Y., Dong, S. Zheng, X., and Wang, Y. 2020. An improved method for the identification of soybean resistance to Phytophthora sojae applied to germplasm resources from the Huanghuaihai and Dongbei regions of China. Plant Dis. 104:408-413.

Yu, A. L., Xu, P. F., Wang, J. S., Zhang, S. Z., Wu, J. J., Li, W. B., Chen, W. Y., Li, N. H., Fan, S. J., Wang, X., and Jiang, L. Y. 2010. Genetic analysis and SSR mapping of gene resistance to Phytophthora sojae Race1 in soybean cv Suinong10. Chin. J. Oil Crop Sci. 32:462-466.

Zhang, J. Q., Sun, S. L., Wang, G. Q., Duan, C. X., Wang, X. M., Wu, X. F., and Zhu, Z. D. 2014. Characterization of Phytophthora resistance in soybean cultivars/lines bred in Henan province. Euphytica 196:375-384.

Zhang, J. Q., Xia, C. J., Duan, C. X., Sun, S. L., Wang, X. M., Wu, X. F., and Zhu, Z. D. 2013. Identification and candidate gene analysis of a novel Phytophthora resistance gene Rps10 in a Chinese soybean cultivar. PLoS One 8:e69799.

Zhao, P., Zhang, G., Wu, X., Li, N., Shi, D., Zhang, D., Ji, C., Xu, M., and Wang, S. 2013. Fine mapping of $R p p P 25$, a southern rust resistance gene in maize. J. Integr. Plant Biol. 55:462-472.

Zhong, C., Li, Y., Sun, S., Duan, C., and Zhu, Z. 2019. Genetic mapping and molecular characterization of a broad-spectrum Phytophthora sojae resistance gene in Chinese soybean. Int. J. Mol. Sci. 20:1809.

Zhong, C., Sun, S., Yao, L., Ding, J., Duan, C., and Zhu, Z. 2018. Fine mapping and identification of a novel Phytophthora root rot resistance locus RpsZS18 on chromosome 2 in soybean. Front. Plant Sci. 9:44.

Zhu, Z., Huo, Y., Wang, X., Huang, J., and Wu, X. 2007. Molecular identification of a novel Phytophthora resistance gene in soybean. Acta Agron. Sin. 33: 154-157. 